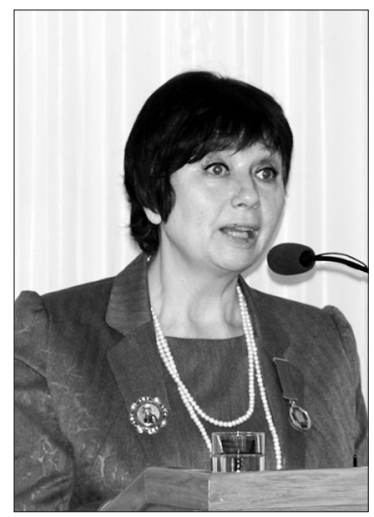

\author{
Larisa Gustowa \\ (Mińsk)
}

\title{
ЦЕРКОВНАЯ МУЗЫКА И ЕЕ ДУХОВНОЕ ВОЗДЕЙСТВИЕ
}

Ключевые слова:

Тип восточнославянского церковного пения (церковной музыки) сформировался на основе византийской христианской литургической культуры, в основе которой лежат имплицитная и эксплицитная формы эстетики и ее компоненты и категории. Наше утверждение, что литургическая музыка является эстетическим феноменом, опирается на определение В. Бычкова, что эстетика - это наука о гармонии человека с Универсумом (Богом); наука о таком опыте освоения реальности, который основан на созерцании или выражении в чувственно воспринимаемой форме абсолютных невербальных (духовных) ценностей, но явленных субъекту в переживании им сопричастности полноте бытия (Божественной жизни) [4, с. 15].

Отцы Церкви трактуют эстетические ценности в качестве квинтэссенции духовной культуры, которая отражает действие Святого Духа как в культуре, так и в человеческой личности. Стяжание Святаго Духа составляет цель жизни христианина, который, по словам Дионисия Ареопагита, должен «взойти на высочайшую высь к божественным и благим лучам» [9, с. 281] и «...подобающим образом петь и воспевать Его (т.е. сверхбла- 
гословенное и всеблагословенное Богоначалие) богоприимными умами» $[9$, с. 119]. Таким образом, целью церковной музыки Дионисий Ареопагит видит воспитание «богоприимного ума».

Лучшим средством воспитания у человека богоприимного ума, формирования привычки и любви к молитве является православное богослужебное пение. О пении в христианском храме, о роли богослужебной музыки в воспитании христианина, в преображении его души размышляли свв. отцы, осмысливая так называемое «богословие в звуках», создавая учение о христианской музыке.

В целом содержание раннехристианской культуры составлял догмат о всепрощающей любви Бога к людям. Ответить на любовь Бога человек может, познавая Его, преображая с Божией помощью свою душу, свое сознание, чтобы, в конце концов, стать подобным Богу. «Вы ... сограждане святым и свои Богу, объявляет апостол Павел [2, Ефс. 2:19].

По мнению свв. Отцов, христианская музыка помогает человеку в процессе духовного преображения: отрешению от мирской суеты, чувственности, погружению в созерцание вечных абсолютных истин, в глубины собственного духа, что отвечает учению Священного Писания [2, 2 Тим. 3:17].

Тертуллиан, подчеркивая новое, христианское, наполнение духовной культуры общества, обозначил и новые эстетические ценности христианского искусства - простоту, естественность и истинность.

Истина выше каких бы то ни было искусств, она не требует украшений, потому что самому Богу присуща простота и поэтому все простое угодно Ему, - утверждал Арнобий (VI в.). Отсюда и в эстетике христианства простота становится основой красоты.

Отцы Церкви заметили, что богослужебная музыка, при всей ее простоте и безыскусности оказывает сильное эмоциональное воздействие на верующих и способствует усвоению словесного содержания песнопений. Св. Василий Великий, епи- 
скоп Кессарийский, подчеркивал, что стройное пение псалмов обучает души поющих: «Поелику Дух Святый знал, что трудно вести род человеческий к добродетели, что по склонности к удовольствию мы не радим о правом пути, то что делает? К учению примешивает приятность сладкопения, что бы вместе с усладительным и благозвучным для слуха принимали мы неприметным образом и то, что есть полезного в слове. На сей-то конец изобретены для нас стройные песнопения псалмов, что бы и дети возрастом, или вообще не возмужавшие нравами, по видимому только пели их, а в действительности обучали свои души» [7, с. 63].

Это свойство христианской музыки отмечал Лактанций, говоря, что искусства с точки зрения чистой духовности всегда имеют практическое значение; они должны способствовать более приятному преподнесению истины, которая для христиан является абсолютной [3, с. 110]. Св. Иоанн Златоуст, архиепископ Константинопольский, подметил, что Господь установил пение псалмов, дабы из этого мы получали удовольствие и пользу $[11$, c. 152].

Святые Афанасий Александрийский, Аврелий Августин, Василий Великий, Иоанн Златоуст подчеркивали, что литургическая музыка тогда выполняет свою функцию, когда способствует проникновению мысли в священный текст, помогает понять и почувствовать его, благодаря чему изложенные в нем положения закрепляются в памяти верующих [3; 5].

Блаженный Августин, епископ Иппонийский, так вдохновенно писал в своей «Исповеди» о впечатлениях во время исполнения христианских песнопений: «Звуки эти вливались в уши мои, истина отцеживалась в сердце мое, я был охвачен благоговением; слезы бежали и хорошо мне было с ними» $[1$, c. 239]. Для бл. Августина новая христианская музыка стала символом новой жизни. Делая символические обобщения, выдающийся богослов связывал музыку с истиной, красотой и мудростью. 
Таким образом, тексты богослужебных песнопений, излагающие истину, эмоционально окрашенные музыкальным элементом, помогают учению и воспитанию личности. Истина излагается в богодухновенных текстах песнопений, которые содержат догматы веры и объяснение их, новозаветные прообразы известных библейских событий и пророчества, исторические события и толкование их духовной значимости, объяснение духовной сути того или иного требования Церкви и т.д.

Апологеты и отцы Церкви, руководствуясь древнегреческим учением о мощном психофизическом влиянии музыки на человека, наполня я его новым духовным содержанием, анализируя собственный опыт, развивали античное учение об этосе. Климент Александрийский делит музыку на полезную и вредную для человека. Вредной он считает музыку, которая разнеживает и расслабляет душу. Полезной - ту, что улучшает и смягчает нрав человека. Климент, изучая мелодические и метро-ритмические особенности современного ему музыкального языка, их экспресивнопсихологические функции (возбуждение в слушателе тех или иных чувств), пишет о бесстрастных и целомудренных мелодиях, которые своей серьезностью и строгостью в зародыше предупреждают бесстыдство, пьянство, склонность к жизни бездеятельной и беспорядочной [5, с. 182].

Климент Александрийский стремился осмыслить и применить к новому мировоззрению известную древнегреческую теорию о музыке космоса [8, с. 289-292]. Пифагорейская музыкально-космологическая терминология наполняется у него образно-символическим содержанием: весь мир представляется Клименту гармонией; человек - прекрасным одушевленным инструментом. Нарушения этой гармонии, допущенные по вине человека, и призвана устранить с Божией помощью христианская церковная музыка [5, с. 182].

Бл. Августин спустя два века развил эту мысль Климента, утверждая, что именно музыка призвана восстановить (с Божией помощью) разрушенную в результате грехопадения человека 
гармонию мира. Жизнь же христианина должна стать музыкой, ликующей песнью, воспевающей хвалу Творцу. Бл. Августин, характеризуя музыку как к искусство в собственном смысле слова, впервые обосновал назначение музыки в христианской культуре, проанализировав вопросы теории музыки (например, ритмически-числовые ее основы), критерии эмоциональной и рациональной ее оценки, символическое значение музыки и музыкальных инструментов [5, с. 480-481].

Апологеты новой христианской культуры утверждали, что христианская музыка, может вызывать и передавать духовную радость. Бл. Августин считал, в музыкальных звуках хорошо выражаются такие состояния души, которые не могут быть выражены словами. Тогда то, что волнует сердце, то, что проистекает непосредственно из эмоциональных глубин души, - претворяется в музыкальной форме, которую мыслитель называет юбиляцией. Форма юбиляции представляла певцу большие возможности для художественного творчества, а музыка в форме юбиляции представлялась бл. Августину единственным непосредственным способом общения души с Богом. Подобное явление в церковной музыке (юбиляция) не подрывало приоритет богослужебного текста, а передавало сильнейшие импульсы не столько разуму, сколько эмоциональному чувству всех участников богослужения, отчего увеличивалось его эмоциональное воздействие.

Св. Афанасий Александрийский заметил, что музыка не только соответственно настраивает души людей слушающих, но также выступает еще и символом, знаком душевного состояния поющего. Св. Афанасий синтезировал античную теорию «музыкального этоса» со знаково-символической теорией музыки [5, с. 110].

Его мысль развил св. Иоанн Златоуст, который писал: «... мы поем не для людей, но для Бога, который может слышать сердца и проникать в сокровенную глубину нашей души... Здесь требуется целомудренная душа, бодрый ум, сердце сокрушенное, по- 
мысел твердый, совесть чистая» [10, с. 153]. Заметим, что св. Иоанн Златоуст подчеркивал сакральный, мистический смысл богослужебной музыки. Константинопольский епископ впервые сформулировал требования, которые должны предъявляться церковному певцу: целомудренность, трезвость (бодрость) ума, борьба со своими грехами (сердце сокрушенное), чистые мысли и намерения (помысел твердый) и чистая совесть, не отягощенная преступлениями против Бога, ближних и против себя самого. Византийский мыслитель ставил в прямую зависимость нравственные качества церковного певца и качество исполнения им богослужебных песнопений.

Задача христианской богослужебной музыки состоит и в создании благоприятной атмосферы для молитвы (когда помыслы молящихся становятся возвышенными и искренними). Св. Афанасий Александрийский подчеркивал, что пение богослужебных песнопений, псалмов, способствует отрешению души от страстей и обыденных чувств и ориентирует ее на достижение вечного блаженства [3, с. 110].

Идеи ранней патристики в отношении христианской музыки (богослужебного пения) в последствии развили византийские богословы и гимнографы святые Иоанн Дамаскин, Феодор Студит, Патриархи Константинопольские Никифор I, Герман и другие деятели литургической музыкальной культуры.

B VII веке, который считается смутным временем в истории Византии, произошел упадок гимнографии в византийской богослужебной культуре, что стало следствием утраты византийским обществом прежнего интереса к религиозной жизни, влечения к аскезе и монашеству [12]. Трулльский собор 681 года отметил не только религиозное, но и глубокое нравственное падение нравов империи и возврат к язычеству, еще уцелевшему в жизни и обычаях народа. В 726-843 гг. Церковь перенесла самый страшный внутренний кризис во всей своей истории - иконоборчество. Именно в этот тяжелый период внимание богос- 
ловов привлекает эстетика красоты. Св. Иоанн Дамаскин, выражая общее мнение отцов Церкви, утверждал, что «божественная красота блистает не какой-нибудь фигурой или благодаря какой-то прелести красок, и потому ее нельзя изобразить...» [10, c. 56]. Мысли св. Иоанна Дамаскина развил св. Феодор Студит (IX в.), который считал, что те, кто увлекается красотой материальной, плотской пребывают в «ослеплении, относительно того, что прекрасно» $[13$, с. 2]. Патриарх Никифора I уточнил, что духовные красоты наполняют небо, а душа украшается «дивной красотой» добродетелей, благочестия и праведности [10, с. 147]. В религиозной эстетике «иконоборческого» периода и в последующем разрабатывались такие глобальные проблемы как знак, символ, образ, икона, проблема литургического образа.

На основе учения святых отцов осмысливался синтез искусств православного храма, представляющий иконообраз Христа, образ Царствия Божьего.

В это время сакральный топос формировался в динамическом пространстве богослужебного действия со всеми его составляющими - особой „режиссурой” света и тени, пения и пластики, звуков и запахов. Важной проблемой богословия стало осмысление новых функций искусства, новых задач, стоящих перед ним, новых принципов его формирования.

Итак, христоцентричное сознание византийских апологетов и богословов создало новое учение о христианской музыке, апеллируя совершенно особыми критериями, выражающими как рациональное, так и эмоциональное начало богослужебного музыкально-певческого искусства. Важнейший тезис христианского учения о музыке заключает в себе понятие, что литургическое пение - не самостоятельное искусство, а форма богослужения и поэтому зависит и обусловлено его смыслом.

Следовательно, музыкальное оформление богослужения должно служить более динамичному его сопереживанию. Текст песнопений, который содержит в себе глубокие религиозные 
мысли, должен быть подан музыкой в таком эмоциональном ракурсе, чтобы эти идеи запечатлелись в сознании верующих. Литургический текст должен быть музыкально оформлен при помощи простых средств, которые бы не мешали, а помогали воспринимать этот текст.

Богослужебное пение - это само богослужение. В богослужении Православной Церкви звучит только пение, т.е. вокальная музыка, инструменты не используются. Некоторые отцы Церкви объясняли эту традицию тем фактом, что инструментальная музыка широко применялась язычниками в их культовых церемониях. Так, сравнивая христианские богослужения с языческими обрядами, где пение соединялось с инструментальным сопровождением, Климент Александрийский подчеркивал, что христиане в качестве инструмента пользуются для прославления Бога единственно мирным словом (логосом), и не трубой, тимпаном или флейтой, которые использовались военными в хоровых плясках, возбуждая чувственность [6, с. 182-183].

Древние богословы объясняли, что христиане славят Бога не безжизненными, бездушными инструментами (например, псалтирью, которая употреблялась иудеями в ветхом завете), но благороднейшим естественным инструментом - человеческим голосом.

Апологеты Церкви аллегорически осмысливали музыкальные инструменты и призыв псалмопевца Давида славить Бога при помощи музыкальных инструментов: «Хвалите Его со звуком трубным, хвалите Его на псалтире и гуслях. Хвалите Его на тимпанах и ликами, хвалите Его на струнах и органе. Хвалите Его на звучных кимвалах, хвалите Его на кимвалах грамогласных...» [2, Пс. 150: 3-5]. Климент Александрийский, трактуя приведенные строки 150 псалма, рассматривает человека в качестве звучащего музыкального инструмента и пишет, что человек анатомически устроен как мирный музыкальный инструмент, а все прочие инструменты, если рассудить, окажутся воинственными $[6$, с. 183]. 
Такое понимание человека как совершенного инструмента и сформировало в христианском церковном сознании представление о церковной музыке как музыке исключительно вокальной, музыке без инструментального сопровождения. Таким образом, раннехристианская эстетика воспринимала вокальную музыку как искусство возвышенного рода, соответствующее чистому созерцанию.

Благодаря природе человеческого голоса, способного своим тембром и пластичностью выражать самые различные чувства, особенно в соединении с текстом, вокальное исполнение богослужебных песнопений способно производить на слушателей глубокое и неотразимое впечатление. Блаженный Августин, вспоминал слезы, которые он проливал при звуках церковного пения в начале рождения его веры, и подчеркивал, что его трогало и само пение, и то, о чем поется [1, с. 296-297].

Даже не учитывая многовековую связь инструментальной музыки с языческими культами, то и тогда очевидно стремление христианской музыкальной эстетики к вокальному началу в оформлении музыкального элемента богослужения. Вокальное исполнение литургических песнопений передает сокровенные чувства исполнителя, вызывает ответную эмоциональную реакцию реципиента; кроме того, голосом можно пользоваться независимо от внешних факторов.

В учении отцов Церкви, так же, как и в образах церковного искусства развивалась идея его богоданности, богодухновенности. Моменты творчества под действием Святого Духа запечатлены на древних иконах (например, образ Покрова Пресвятой Богородицы), в Евангельских миниатюрах, в устных преданиях о певцах древней Церкви (например, предание о знаменитом византийском певце св. Романе Сладкопевце). Факт совместного пения ангелов и людей запечатлен в тексте кондака праздника Рождества Христова: «...ангели с пастырьми славословят», в тексте кондака празднику Покрова Пресвятой Богородицы: «Дева днесь предстоит в церкви и в лики святых невидимо за ны мо- 
лится Богу. Ангели же со архиереи поклоняются...», в тексте пасхальной стихиры «...ангели поют на небесех, и нас на земли сподоби...» и т.д.

Бесспорно, души поющих и слушающих невидимо связаны между собой. Это явление заметил еще Иоанн Златоуст, который подчеркнул, что все, что есть на душе у поющего, невидимым образом входит в душу слушающего и обучает ее. Слушая церковную музыку слушатель невольно усваивает духовную энергию ее исполнителей. Канонический текст, созданный святыми отцами, - богодухновенен, ему присущ когнитивный аспект, через него происходит усвоение той реальности, которую этот текст отражает. При таких условиях предъявляются определенные требования к духовному состоянию личности (певец, дирижер или регент, композитор), который создает литургическую музыку на канонические тексты.

Кроме ответственности, с которой необходимо осуществлять мелодическую проповедь, необходимо осознавать, что творчество в рамках церковного искусства клиросе является не формой самовыражения, а со-творчеством с Богом-Словом: «...способность наша от Бога», - говорит апостол Павел [2, 2 Кор. 3:5-6]. В каждом осмысленно пропетом песнопении «... открывается правда Божия от веры в веру» [1, Рим. 1:17], поэтому творчество в области церковного искусства является одним из способов богопознания.

В заключение подчеркнем,что церковная музыка моделирует преображенное пространство, результатом которого становится покаянно-радостное молитвенное сердечное расположение и исполнителей, и слушателей, которое, несомненно, способствует духовному развитию личности, которое и называется преображением.

«Устремим же себя молитвами, чтобы взойти на высочайшую высь к божественным и благим лучам...». 


\section{Литература:}

1. Августин, Исповедь / Пер. с лат. и коммент. М. Е. Сергиенко; Предисл. и послесл. Н. И. Григорьевой / А. Августин.- М.: Гендальф, 1992.-544 c.

2. Библия: Книги Священного Писания Ветхого и Нового Завета. Брюссель: Жизнь с Богом, 1989.-2514 с.

3. Бычков, В.В. Некоторые проблемы музыкальной эстетики в ранней патристике // Музыкальная культура средневековья: Сб. науч. тр. / Центральный музей древнерусской культуры и искусства им. А. Рублева; Сост. и отв. ред. Т. В. Владышевская / В. В. Бычков.- М., 1992.- Вып.2.- С. 110-112.

4. Бычков, В. В. Эстетика: учебник / В. В. Бычков. - 2-е изд., перераб., доп. - М.: Гардарики, 2006.- 573 с.

5. Бычков, В. В. Эстетика отцов иеркви = Aestetica patrum / В. В. Бычков.- М.: Ладомир, 1995.- 593 с.

6. Вагнер, Г. К. Искусство древней Руси / Г. К. Вагнер, Т. Ф. Владышевская. - М.: Искусство, 1993.-255 с.

7. Гарднер И. А. Богослужебное пение русской православной церкви: В 2 т.- Сергиев Посад: Московская духовная академия, 1998.- Т.1. -580 c.

8. Герцман, Е.В. Музыка Древней Греизии и Рима / Е. В. Герцман.- СПб.: Алетейя, 1995.- 336 c.

9. Дионисий, Ареопагит. Сочинения. Максим Исповедник. Толкования / Дионисий Ареопагит, Максим Исповедник. - СПб.: «Алетейя»; «Изд-во Олега Абышко», 2002.- 864 с.

10. Иоанн Дамаскин. Три защитительных слова против порицающих святые иконы или изображения / Иоанн Дамаскин.- М.: СвятоТроицкая Сергиева лавра; РФМ, 1993.- 168 с.

11. Иоанн Златоуст. Творения: В 12 т.- СПб.: С-Петербургская духовная академия, 1899.- Т. 5, кн. 1.- 412 с.

12. Успенский Ф. И. История византийской империи / Сост. Т.В. Мальчикова.- М.: Мысль, 1996.- 827 с.

13. Феодор Студит. Послание Платону о почитании икон.- М.: Свято-Троицкая Сергиева лавра, 1993.- 168 с. 